\title{
The Properties of Nano Silver (Ag)-Geopolymer as Antibacterial Composite for Functional Surface Materials
}

\author{
Armayani. $\mathrm{M}^{1,2, *}$, Muhammad Akbar Pratama ${ }^{1,2}$, and Subaer ${ }^{1,2}$ \\ ${ }^{1}$ Laboratorium Fisika Material, FMIPA, Universitas Negeri Makassar Jalan Daeng Tata Raya, \\ Makassar 90223, Indonesia \\ ${ }^{2}$ Konsorsium Riset Geopolimer Indonesia (KORIGI), Laboratorium Beton dan Bahan Bangunan, \\ Kampus ITS Sukolilo Surabaya, Indonesia, 6011
}

\begin{abstract}
The purpose of this research was to produce and characterize nano silver (Ag)-geopolymer composite for functional surface materials. Geopolymer matrix was synthesized through alkali activation of metakaolin and nano silver was added into geopolymers paste with a mass of $0,0.5 \mathrm{~g}, 1$ $\mathrm{g}, 1.5 \mathrm{~g}$ and $2 \mathrm{~g}$ keeping the mass of metakaolin constant. The mixture was cured at $70^{\circ} \mathrm{C} / 1$ hour and stored for 7 days before conducting any measurements. The structure of the resulting composite was examined by using Rigaku Mini Flex II x-ray diffraction (XRD). Scanning Electron Microscopy (SEM) coupled with Energy Dispersive Spectroscopy (EDS) was used to examine the morphology of the composite surface as well as the capability of the composite to isolate the growth of bacteria. The thermal properties of composites in terms of their working temperature and enthalpy were examined by using Perkin Elmer Differential Scanning Calorimetry (DSC). The heat resistance of composite was observed through calcination at $750^{\circ} \mathrm{C}$ for 18 hours. The results indicate that the resulting composites were able resist up $750^{\circ} \mathrm{C}$. SEM examinations showed that nano Ag-geopolymer composites were effectively restraining the growth of bacteria. It is suggested that nano Ag-geopolymer composites are suitable for functional surface applications such as floor and wall, kitchen ware utensils, hospital instruments, art and decoration materials.
\end{abstract}

\section{Introduction}

Nanotechnology plays important role in the advancement of science and technology. This technology has already find a place in a wide range of physics, chemistry, biology, and medical applications. Nano silver (Ag) is one of the attractive nano materials for antibacterials application. Nano silver has been applied as antimicrobial in public area such as train stations and elevators. It is a well-known fact that silver ions and silver-based compounds are highly toxic to microorganisms which include 16 major species of bacteria [1]. Silver nanoparticles with a size between $1-100 \mathrm{~nm}$ show unique physical, chemical and biological properties which is very much different when in bulk size [2-4]. Nanoparticles have vast surface area relative to volume and therefore minuscule amounts of silver nanoparticles can lend antimicrobial effects to hundreds of square meters of its host material [5].

As antibacterial, the activity of nano silver is influenced by the type and number of bacteria colony as well as time contact between nano silver and bacteria [6]. The size of nano silver will determine the penetration process on the particles into bacteria. Silver's antimicrobial is based on the interaction between free silver ions with specific bacterial cell

* Corresponding author: armha_physics09@yahoo.com 
structure. The silver ions block the enzymatic respiration chain, Ion perak memblokir rantai respirasi enzimatik, cause destruction of the cell membrane (lysis), or to prevent mitosis of these organisms [7].

Composite nano silver-geopolymers can be applied to cover a wall in which $\mathrm{Ag}$ nanoparticles will prevent the formation of biofilm, or the wall of bacteria cell and therefore unable to split [8]. This study was conducted to examine the potential of nano Ag-geopolymer composites to be applied as functional surface, arts dan decoration materials which have unique color and structure [9], as well as material that inhibit the growth of bacteria.

\section{Research Method}

Composite nano silver (Ag)-geopolimers were synthesized through alkali activation of metakaolin. The resulting geopolymer paste was added with silver nanoparticle up to $2 \mathrm{~g}$ keeping the mass of metakaolin constant. The mixture was stirred manually and poured into polycarbonate container and cured at $70^{\circ} \mathrm{C}$ for 1 hour. Silver nanoparticle was prepared from $\mathrm{AgNO}_{3}$ precursor by using the bioreduction method of the extract of catappa (Terminalia catappa) leaves for 4 hours.

The resulting composites were stored in open air for 14 day before commencing any measurements. X-ray diffraction technique was performed to observe the structure of as-prepared and calcined composites at $750^{\circ} \mathrm{C}$. Samples for Scanning Electron Microscopy (SEM) was prepared and stored in oper air to examine the presence of any bacteria on the surface of composites. Differential Scaning Calorimetry (DSC) was performed to study the working temperature and the entalhy of the resulting composites.

\section{Results and discussion}

Figure 1(a) is the morphology of silver nanoparticles prepared through bioreduction method of $\mathrm{AgNO}_{3}$. The SEM image shows that the particle size of silver below $100 \mathrm{~nm}$ and with this size silver nanoparticles have important optical properties, mechanics, and toxicity [10]. Figure 1(b) is the SEM image of metakaolin particles used in this study. The image showed that metakaolin consist of flakes particles similar to those of kaolin.

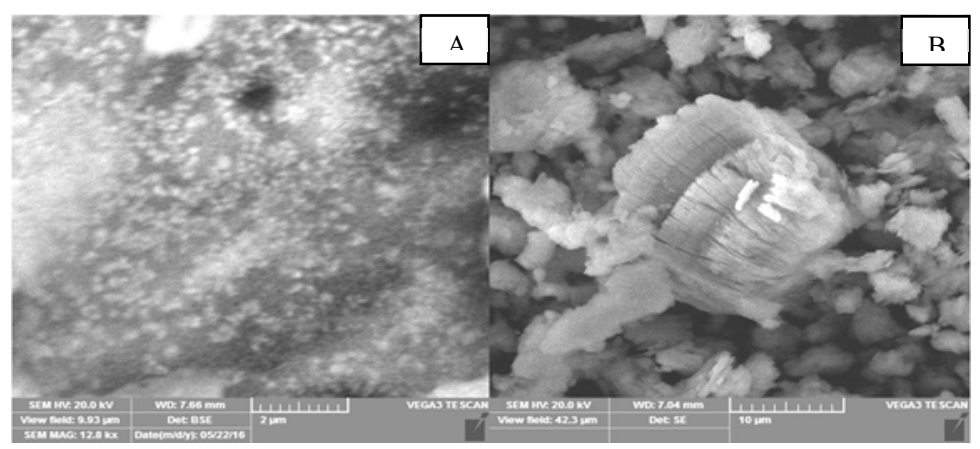

Fig. 1. SEM images of (a) silver nanoparticles, (b) metakaolin 
Table 1 shows the chemical compositions of metakaolin based on EDS measurement.

Table 1. Chemical composition of Silver nanoparticles and metakaolin

\begin{tabular}{|l|c|c|c|c|}
\hline \multirow{2}{*}{ Element } & \multicolumn{2}{|c|}{ Nano-perak (Ag) } & \multicolumn{2}{c|}{ Metakaolin } \\
\cline { 2 - 5 } & $\begin{array}{c}\text { Atom C } \\
\text { [at.\%] }\end{array}$ & $\begin{array}{c}\text { Comp C } \\
\text { [wt \%] }\end{array}$ & $\begin{array}{c}\text { Atom C } \\
\text { [at.\%] }\end{array}$ & Comp. C [wt.\%] \\
\hline Silver & 89.88 & 96.06 & - & - \\
Magnesium & 1.64 & 0.66 & 0.19 & 0.37 \\
Iron & 0.95 & 0.68 & 0.52 & 1.82 \\
Copper & 3.78 & 2.38 & 0.24 & 0.74 \\
Silicon & 0.39 & 0.23 & 15.73 & 45.99 \\
Aluminium & - & - & 19.95 & 49.49 \\
Sodium & - & - & 0.27 & 0.41 \\
Titanium & - & - & 0.19 & 0.72 \\
Potassium & - & - & 0.20 & 0.45 \\
\hline
\end{tabular}

The EDS results showed that the produced silver nanoparticles contain $89.88 \mathrm{wt} \%$ silver and other elements derived from catappa leaves. Metakaolin consists of $45.99 \mathrm{wt} \% \mathrm{SiO}_{2}$ and $49.49 \mathrm{wt} \% \mathrm{Al}_{2} \mathrm{O}_{3}$. Because the weight of $\mathrm{SiO}_{2}$ is lower than $\mathrm{Al}_{2} \mathrm{O}_{3}$ the synthesis of geopolymers requires higher sodium silicate solution.

Figure 2(a) shows the diffractogram of silver nanoparticles showing almost single phase. By using Debye-Scherer equation it was found that the particle size of silver nanoparticles was $21.3 \mathrm{~nm}$. Figure 2(b) is the diffractogram of metakaolin showing the amorphous nature with some minor minerals such as quartz, anatase and dialuminium silicate oxide.

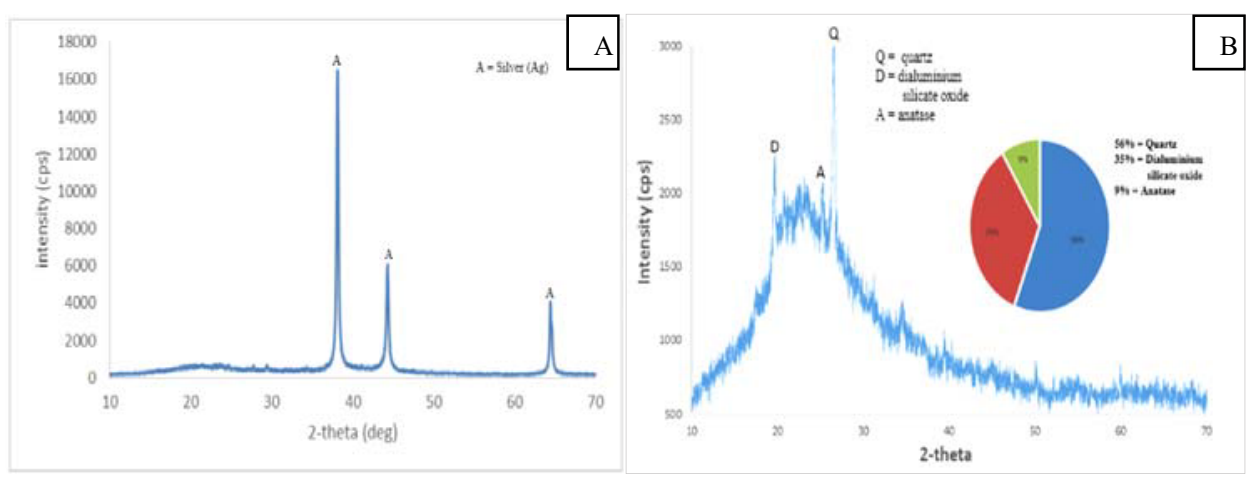

Fig. 2. Diffractograms of (a) silver nanoparticle, (b) metakaolin

Figure 3 shows diffractogram of the resulting composites contain different amounts of nano silver.

It can be seen that the peak of silver is at $38^{\circ} 2 \theta$ and increase as the amount of silver increase. The presence of silver did not influence the overall amorphous structure of geopolymers made from metakaolin. 


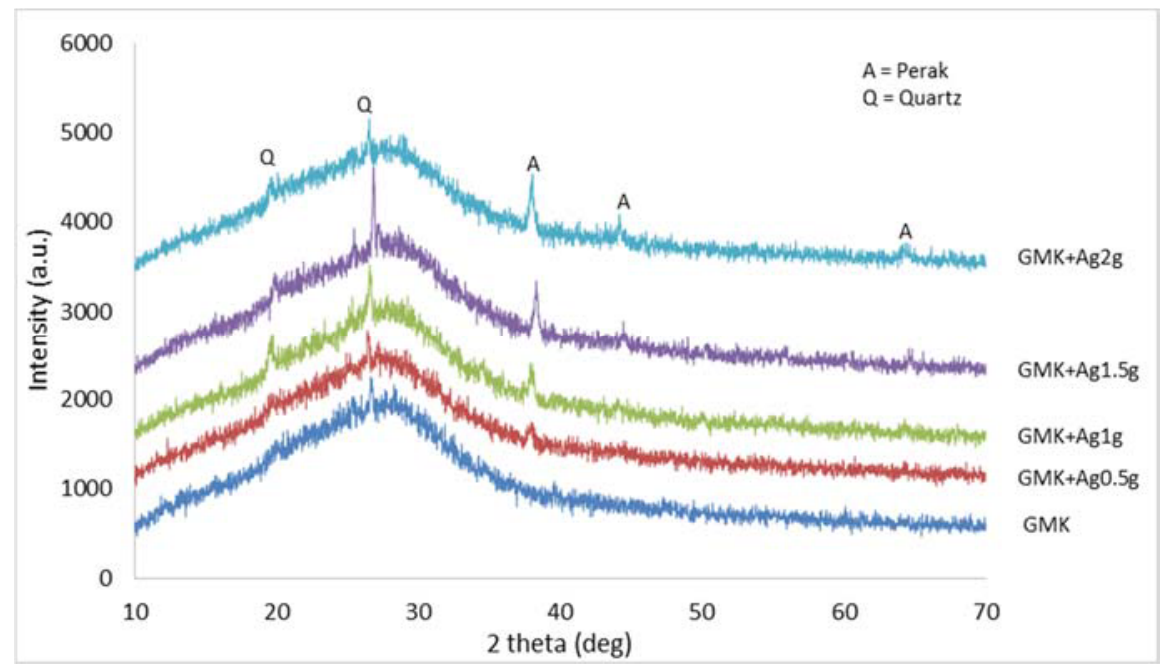

Fig. 3. Diffractogram of composite nano Ag-geopolimers having different amount of Ag

The thermal properties of the resulting composites were studied by means of differential scanning calorimetry (DSC). Figure 4(a) shows DSC result of geopolymer without silver nanoparticle. The measurements were conducted at temperature range from $30^{\circ} \mathrm{C}$ to $400^{\circ} \mathrm{C}$ with a heating rate $20^{\circ} \mathrm{C} /$ minutes and sample mass of $20 \mathrm{mg}$. Geopolymer is an exothermic material and at temperature around $100^{\circ} \mathrm{C}$ water from the interior of geopolymer start to evaporate and results in the first peak at the exothermic curve (figure 4.a).
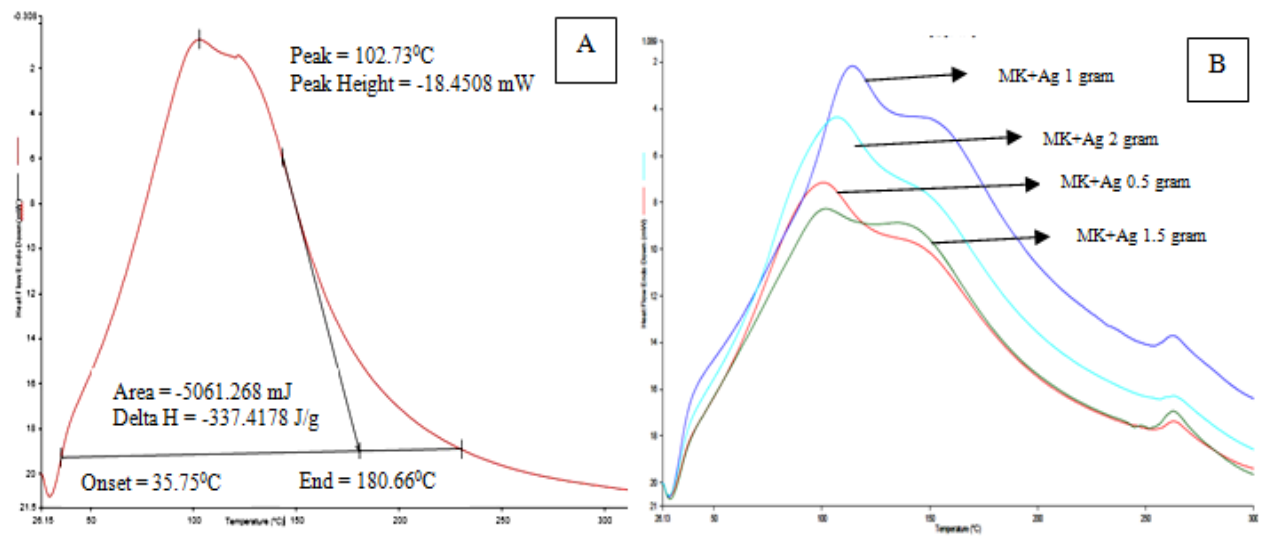

Fig. 4. DSC results of (a) pure geopolymer, (b) Nano silver-geopolymers

The presence of silver nanoparticle in the network of geopolymers change the exothermic profile of this material as can be seen from figure 4 (b). The enthalpy of the composites increase as the mass of silver increase as can be seen in table 2 . The results also showed that the working temperature of the composite reach a value around $200^{\circ} \mathrm{C}$. 
Table 2. DSC results of pure geopolymers and nano silver-geopolymers composites

\begin{tabular}{|l|c|c|c|c|}
\hline \multicolumn{1}{|c|}{ Sample } & $\begin{array}{c}\text { Range Temperature } \\
\left(\mathbf{C}^{\mathbf{0}}\right)\end{array}$ & $\begin{array}{c}\text { Peak Endoterm } \\
\left(\mathbf{C}^{\mathbf{0}}\right)\end{array}$ & $\begin{array}{c}\text { Peak Exoterm } \\
\left(\mathbf{C}^{\mathbf{0}}\right)\end{array}$ & $\begin{array}{c}\text { Enthalpy } \\
(\mathbf{J} / \mathbf{g})\end{array}$ \\
\hline GMK & $55.24-207.77$ & - & 140.98 & 317.91 \\
GMK+Ag 0,5 gram & $50.27-205.97$ & - & 100.89 & 189.09 \\
GMK+Ag 1 gram & $74.82-215.55$ & - & 114.34 & 213.69 \\
GMK+Ag 1,5 gram & $44.28-206.87$ & - & 101.90 & 201.03 \\
GMK+Ag 2 gram & $56.20-194.44$ & - & 106.98 & 230.90 \\
\hline
\end{tabular}

Figure 5 shows the SEM images of composite nano Ag-geopolymers. Figure 5(a) shows the typical morphology of geopolymers surface made from metakaolin. This sample did not contain silver nanoparticles. Figure 5 (b,c,d, and e) shows the morphology of composites surfaces which contain $0.5 \mathrm{~g}, 1.0 \mathrm{~g}, 1.5 \mathrm{~g}$, and $2.0 \mathrm{~g}$ of nano silver and have been exposed to open air before coating with $\mathrm{Pd} / \mathrm{Au}$ for several days. The images show that on the surfaces of all samples contain certain types of bacteria. This indicates that the presence of nano silver on the surface of the samples effectively captured and inhibited the growth of bacteria. Yaohui et.al. [11] reported that nano silver effectively capture 650 types of bacteria.

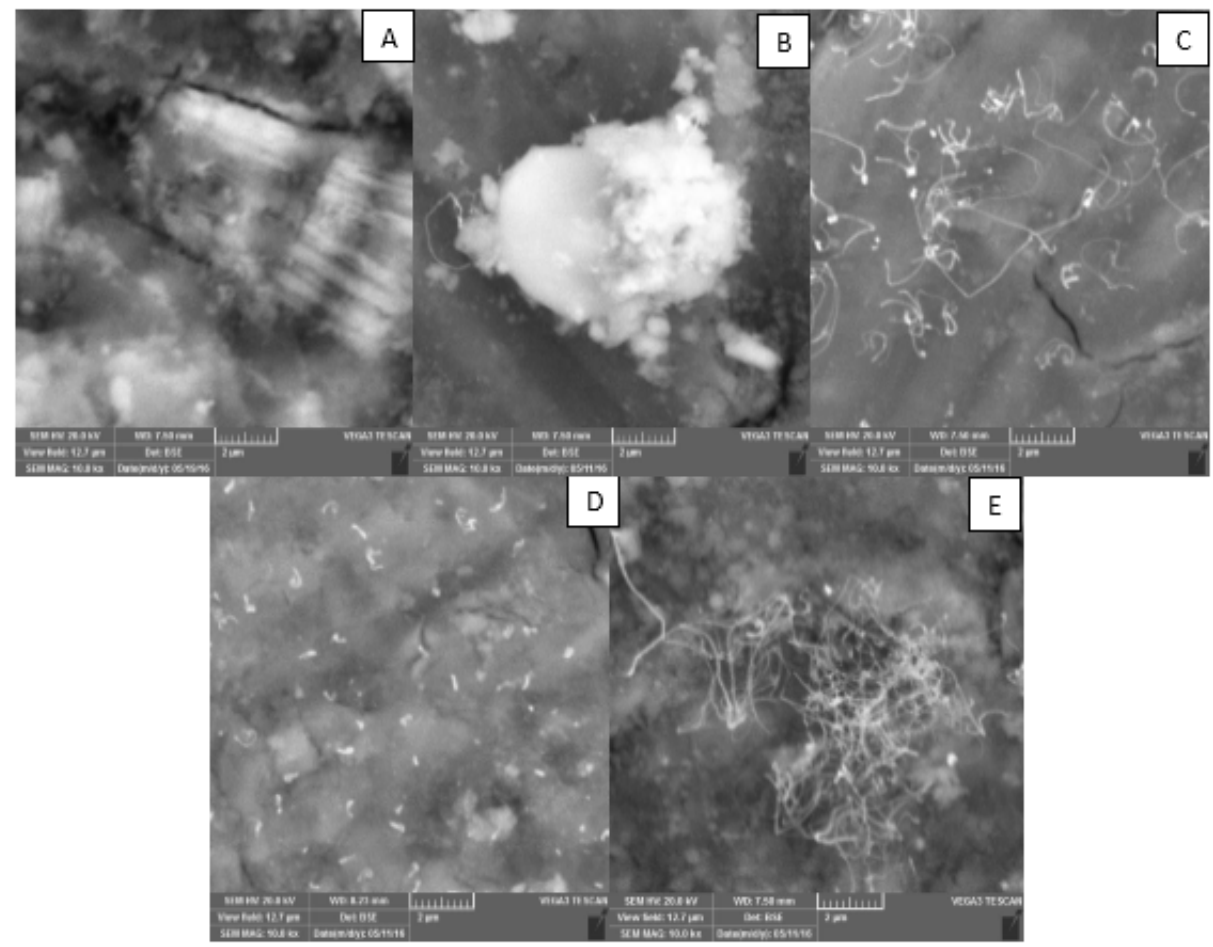

Fig. 5. SEM images of nano silver-geopolymers (a) GMK, b). GMK+Ag 0,5 g, c). GMK+Ag 1g, d.) $\mathrm{GMK}+\mathrm{Ag} 1,5 \mathrm{~g}$, and e). GMK $+\mathrm{Ag} 2 \mathrm{~g}$. Notice the presence of certain bacteria on the surface of each sample.

Figure 6 show that the presence of Nano silver in the network of geopolymers did not reduce the ability of geopolymers to retards heat. Although substantial cracks were observed on the surface of all samples after heat resistance measurement but the integrity of the samples remains strong. The occurrence of cracks was a result of dry shrinkage of the 
samples which start to take place at temperature $100^{\circ} \mathrm{C}[12,13]$. Table 3 shows the bulk density of the sample before and after heat resistance measurement. The reduction of densities of the samples after heat measurements due to substantial cracks on the surface of the samples.

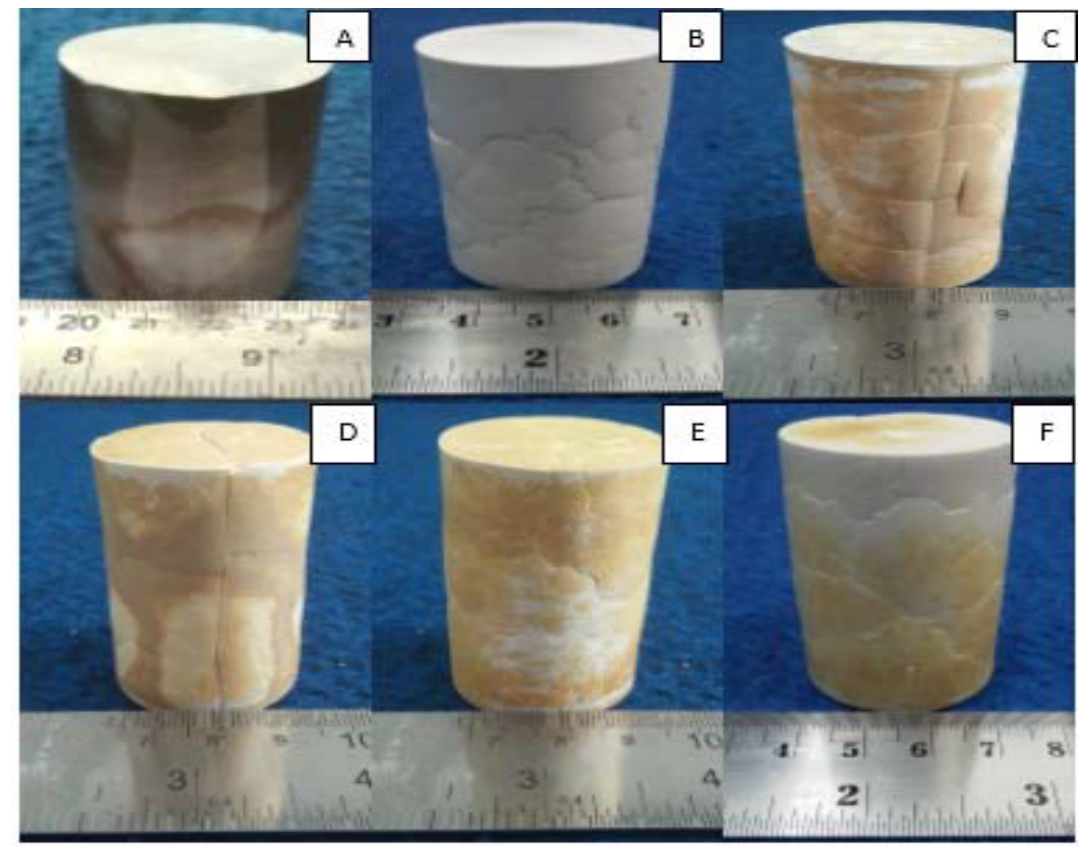

Fig. 6. The appearance of nano silver-geopolymers after heat resistance measurement. (a) as-prepared sample (b) $0 \mathrm{~g} \mathrm{Ag}$, (c) $0.5 \mathrm{~g} \mathrm{Ag}$, (d) $1.0 \mathrm{~g} \mathrm{Ag}$, (e) $1.5 \mathrm{~g} \mathrm{Ag}$, and (f) $2.5 \mathrm{~g} \mathrm{Ag}$.

Table 3. Bulk density of composite Nano silver-geopolymers before and after heat resistance measurement

\begin{tabular}{|c|c|c|}
\hline Sample & $\begin{array}{l}\text { Density as-prepared sample } \\
\qquad\left(\mathrm{g} / \mathrm{cm}^{3}\right)\end{array}$ & $\begin{array}{c}\text { Density after heat resistance } \\
\text { measurement } \\
\left(\mathrm{g} / \mathrm{cm}^{3}\right)\end{array}$ \\
\hline GMK & 1,71 & 1,58 \\
\hline $\mathrm{GMK}+\mathrm{Ag} 0.5 \mathrm{~g}$ & 1,76 & 1,66 \\
\hline $\mathrm{GMK}+\mathrm{Ag} 1 \mathrm{~g}$ & 1,94 & 1,67 \\
\hline $\mathrm{GMK}+\mathrm{Ag} 1.5 \mathrm{~g}$ & 1,74 & 1,60 \\
\hline $\mathrm{GMK}+\mathrm{Ag} 2 \mathrm{~g}$ & 1,75 & 1,57 \\
\hline
\end{tabular}

\section{Summary}

Functional composite nano silver-geopolymer based on metakaolin have succesfully produced and characterised. Silver nanaparticles was produced through bioreduction method (solution of catappa leaves) of $\mathrm{AgNO}_{3}$. The composites were able to inhibit certain types of bacteria which indicate that the presence of nano silver works effectively as microbial agent. The resulting composites also showed excellent properties as heat resistance material. The result of this study suggest that functional composite nano silver-geopolymers can be applied as antimicrobial material. 


\section{References}

1. S. Prabu, E.K. Poulose, Int. Nano Lett., (2012)

2. J. Palanivelu, M.M. Kunjumon, A. Suresh, A. Nair, Dr. Ramalingam, J. Pharm. Sci. Res., 7, 690 (2015)

3. J.R. Morones, J.L. Elechiguerra, A. Camacho, K. Holt, J.B. Kouri, J.T. Ramirez, M.J. Yacaman, Nanotechnology, 16, 2346 (2005)

4. K. Burridge, J. Johnston, T. Borrman, J. Mater. Chem., 21, 734 (2011)

5. T. Theivasanthi, M. Alagar, Anti-bacterial Studies of Silver Nanoparticles. arXiv preprint arXiv (2011)

6. N. Beyth, Y.H. Haddad, A. Domb, W. Khan, R. Hazan, J. Evidence-Based Complementary Altern. Med., (2015)

7. Herman, Raumedic Infect-Protect., (2010)

8. B. Domenech, M. Munoz, D.N. Muraviev, J. Macanas, Polymer-Silver Nanocomposites as Antibacterial materials. Microbial Pathogens and Strategies for combating them: Science, Technology and Education. (2013)

9. G. Grimal, A.F. Sculptor and Painter, Potential utilizations in Art and Decoration Georges Grimal. Geopolymer Institute. (2006)

10. Y. Masakke, Sulfikar, M. Rasyid, Biosynthesis of Silver Nanoparticles Using Methanol Extract of Mangosteen Leaves (Garcinia Mangostana L.). Journal Sainsmat. IV (2014)

11. Y. Lv, H. Liu, Z. Wang, L. Hao, J. Liu, Y. Wang, G. Du, D. Liu, J. Zhan, J. Wang, Polym. Adv. Technol., 19, 1455 (2008)

12. Subaer. Pengantar Fisika Geopolimer. Direktorat Jenderal Pendidikan Tinggi. (2012)

13. Z. Zuhua, Y. Xiao, Z. Huajun, C .Yue, Journal of Applied Clay Science. 43, 218 (2009) 